\title{
On its path to become 'North European': political climate change narrative in Latvia
}

\author{
VINETA KLEINBERGA \\ Rīga Stradinš University, Latvia \\ vineta.kleinberga@rsu.Ivl
}

\begin{abstract}
:
The European Green Deal is the European Union's latest expression of its ambition to become a world leader in addressing climate change. This study seeks to examine how Latvia - an EU member state deals with the change brought about by a changing climate and the EU's response to it. Informed by a strategic narrative approach, this study demonstrates that Latvia - originally hesitant to address climate change - has rebranded and repositioned itself as an active promoter of carbon neutrality, meanwhile constructing an identity narrative of Latvia as a pragmatic and reliable EU partner by embracing an image of a North European country at the government level. The narrative seeks to appeal to a Nordic life-style and resonates with levels of social welfare that Latvia aspires to achieve. By exploring how EU member states construct identity narratives around the EU's institutional constraints, this study adds the dimension of narratives and perceptions to processes of Europeanisation.
\end{abstract}

Key words: climate change, Europeanisation, Latvia, strategic narrative

\section{Introduction}

The European Union (EU) has worked continuously to harmonise policies, governance and legislation, resulting in common policies and an enhanced role of the EU in the world as a global leader in addressing climate change. Yet, the role of member states is decisive in the implementation of EU ambitions. This study draws on the new institutionalist approach (Hall \& Taylor, 1996), assuming that member states are rational actors, yet form their preferences within pre-established institutional constraints. In Europeanisation studies "institutions are classically understood as formal rules, standard operating procedures, and governmental structures" that limit the choices actors have (Graziano, 2012, p.11). This study focuses on Latvia - one of the EU member states - and its efforts to deal with change in the context of an institutional setting that is defined by the 20192024 European Commission's ambitious climate policy. Latvia has long been "hesitant" about EU's climate targets, yet recently joined the "forerunners" (Ruse, 2013) in advocating for an ambitious carbon-neutrality strategy for the EU. Arguably, it is a particular institutional constraint of Latvia - its obligation to align with the EU climate policy and an overall consensus on the necessity to implement the European Green Deal (EGD) - that has facilitated Latvia's move towards a pragmatic narrative on climate change. Following the "logic of consequences" of rational institutionalists the "government adopts EU rules if the benefits of EU rewards exceed the domestic adoption costs" (Schimmelfenning \& Sedelmeier, 2005, p.10). Yet, how does Latvia position itself 
as a pragmatic partner both to domestic and international audiences? What is the language the government uses to legitimise Latvia's strategic goals in the climate policy?

This article draws on the concept of strategic narratives to examine how the EU's climate targets are incorporated into the logic of Latvia's political discourse. In this study, I focus on identity narratives at the formation phase. I ask how the Latvian government constructs its narrative by looking at certain elements of the narrative structure (Roselle, Miskimmon \& O'Loughlin, 2014). In the first section, I explain the strategic narrative framework and propose a methodology for operationalising research on Latvia's official political identity narrative. In the second section, this article examines the status quo of climate change discourse in Latvia, by demonstrating changes to representations of climate change in Latvia's policy planning documents since coming to power of Prime Minister Krišjānis Karin̄š ('New Unity'). ${ }^{1}$ In the third section, I focus on the construction of Latvia's identity narrative as a 'Nordic country', using the empirical data from speeches of Kariňš. In conclusion, I demonstrate that the Latvian government has forged a narrative of Latvia as a North European country to rebrand itself as a pragmatic and reliable EU partner at the EU level, while focusing on the level of welfare of the Nordic countries as Latvia's path of development at the domestic level. Importantly, policy behaviour in tackling climate change complements narratives at both levels.

This study contributes to EU studies by complementing rational institutionalist explanations of Europeanisation with the dimension of strategic narratives, which uncovers how narratives can be used to legitimise adoption (or not) of certain EU norms within particular institutional constraints. It also complements research on the perception of the EU and its policies (Chaban \& Holland, 2014; Chaban, Miskimmon, \&O'Loughlin, 2017). Last but not least, the study provides an empirical case study from a post-2004 EU accession country, thus complementing the work of scholars who explore climate change related media discourses, narratives and frames in the region (Cernoch Lehotský, Ocelík, Osicka \& Vencourová, 2019; Kundzewicz, Painter \& Kundzewicz, 2019; Lehotsky, Cernoch, Osicka \& Ocelík, 2019; Osička, Kemmerzell, Zoll, Lehotský, Černoch, \& Knodt, 2020).

\section{Strategic narrative theory: analytical framework and methodology}

The study is inspired by the concept of strategic narratives, developed to improve an understanding and analysis of soft power in international relations, especially nowadays when "we have a chaotic world, with leaders who are ill-equipped for its complexities" (Roselle, Miskimmon \& O'Loughlin, 2014, p. 74). Narratives help to order the chaos (Roselle, Miskimmon \& O'Loughlin, 2014), thus allowing actors to navigate among narratives, aligning with or contesting them. Although narratives have always existed in societies and shaped people's understanding of the world (Bruner, 1991), strategic narratives are "a means for political actors", which they use to "construct a shared meaning of the past, present and future of international politics to shape the behaviour of domestic and international actors" and "to extend their influence, manage expectations, and change the discursive environment in which they operate" (Miskimmon, O'Loughlin \& Roselle, 2013, p.2). Strategic narratives are, therefore, important for organising and making sense of power relations, and serve as crucial means for actors to persuade other actors into pursuing similar objectives. However, the persuasiveness of a strategic narrative depends not only on the actor itself: narratives are contested by other actors who

${ }^{1}$ Liberal centre-right party. 
have their own sources of information, knowledge, value systems, economic, educative, social and cultural backgrounds.

While narratives in international relations come in three forms - system, issue and identity narratives (Miskimmon, O'Loughlin \& Roselle, 2013) - this study focuses on the identity narrative of Latvia at the formation phase, aiming to uncover which 'story' Latvia tells about tackling climate change and which values and goals are embedded in it. Miskimmon, O'Loughlin \& Roselle (2013, p. 30) demonstrate the importance of narratives for processes of identity formation, by arguing that it is through narratives that "actors are given meaning to themselves and others". Importantly, strategic narratives can become binding once set and strategic narratives not only inform actor's preferences and are means to "shape the behaviour" (Miskimmon, O'Loughlin \& Roselle, 2013, p.2) of other actors but simultaneously structure and condition an actor's behaviour.

In order to operationalise research on strategic narratives, I draw on qualitative content analysis. Observing that change in Latvia's stance towards climate change was initiated by Prime Minister Kariņš whose government was installed on 23 January 2019, this study focuses on the formation phase of Latvia's political narrative since then. I analyse several types of sources:

1. Latvia's long- and medium-term strategic and policy planning documents: National Security Concepts since 1991, Foreign Policy Reports since 2011, National Development Plans for 2014-2020 and 2021-2027, National Plan for Adaptation to Climate Change until 2030, Strategy for Carbon Neutral Development until 2050, and National Energy and Climate Plan for 2021-2030;

2. Eight speeches of Kariņš as Prime Minister, available to the general public up to May 2020.

According to Roselle, Miskimmon \& O'Loughlin (2014, p. 79) elements of a narrative structure include: "a set of characters or actors, a space or environment, a conflict or action, and resolution". Actors are main characters in a narrative, embodying certain characteristics and behaviour. Space or scene demonstrates the context, sets the scale and the thematic framework of a particular action. Action involves events around which the interaction with actors, often involving conflict, takes place. Resolution or proposed resolution indicate future options for actors and desired outcomes either by restoring a disrupted order or changing it. Narratives thus involve a dimension of time, in addressing how narrators see past, present and future. Adapting from Roselle, Miskimmon \& O'Loughlin (2014), I use a protocol for analysis that looks at (1) actors, (2) scene, (3) action, and (4) time.

\section{Climate change in Latvia's strategic and policy planning documents since 2019}

Latvia joined the EU in 2004, but has long been negligent in nationally embedding climate targets. Formally, Latvia is part of the United Nations Framework Convention on Climate Change and it has ratified both the Kyoto Protocol (in 2002) and the Paris Agreement (in 2017). However, Latvia's policy has always been at a minimum to meet the EU requirements. Ilze Ruse (2013) names Latvia the "hesitant" nation in contrast to the "forerunners" Denmark, Finland and Sweden, when climate change mitigation obligations in the EU are addressed. 
Traditionally, Latvian politicians and policymakers have justified doing the minimum by pointing to Latvia's past achievements, mainly Latvia's high proportion of hydropower in its energy mix (Investment and Development Agency of Latvia, 2015). As a result, the share of renewables in Latvia's energy consumption is already higher than in the EU on average (see Eurostat, 2020b). Besides, the myth of Latvia being the "second greenest country in the world" (Baltic News Network, 2012) has long been alive in people's minds and has helped to disguise the minimum activity in tackling climate change (see Emerson, Hsu, Levy, de Sherbinin, Mara, Esty \& Jaiteh, 2012). Latvia's National Development Plan for 2014-2020 states that "Latvia continues to be one of the greenest countries in the world" (Cross-Sectoral Coordination Centre of Latvia, 2014) even though in 2018, Latvia was ranked only the 37th 'greenest' country in the world (Wendling, Emerson, Esty, Levy, de Sherbinin, 2018). Furthermore, public pressure on politicians in Latvia is not high. In 2019, only $11 \%$ of Latvians considered climate change to be the most serious problem in the world, while only $4 \%$ considered it to be the most important issue facing Latvia (European Commission, 2019).

A turning point in Latvia's official attitude towards climate change happened in the 2018 general election and with Prime Minister Kariňš coming to power on 23 January 2019. Kariňš states (Cabinet of Ministers, 2019) that from a "passive country that reluctantly accepts, what others have decided" Latvia should become "one of the main promoters" of climate policy in the EU. With this announcement, Kariňš joined Belgium, Denmark, France, Luxembourg, the Netherlands, Portugal, Spain and Sweden in demanding more ambitious EU climate policies during the Sibiu Summit of EU leaders in Romania on 10 May 2019.

Since then several developments in Latvia's long and medium-term strategic and policy planning documents can be observed, emphasising the necessity for Latvia to become a more active player in climate policy. First, for the first time since the 1990s, climate change has been emphasised as a threat in Latvia's main strategic planning document - Latvia's National Security Concept (Saeima, 2019a). Climate and climate change were mentioned four times, in contrast to the absence of either term in previous versions of the document. In parliamentary debates on the National Security Concept, the Deputy Speaker of Parliament Inese Libina-Egnere ('New Unity') (Saeima, 2019b) emphasises that climate change is "one of such global risks, which we cannot afford to ignore [...] Climate change - it is not a matter of fashion, it has already caused socio-economic damage to the EU Member States, including Latvia”. Latvia's National Security Concept provides the basis for a system narrative of global insecurity, caused by climate change and its threat to the existence of humanity. As such, it underlines the international security dimension of climate change and sets the scene for Latvia's action: climate change is real; it is a global threat in a world full of uncertainties.

Second, climate change has become an increasingly visible part of Latvia's annual Foreign Policy Reports and debates - the main forum for Latvian politicians to define and negotiate Latvia's foreign policy goals, taking place in January of each year in parliament and informing Latvia's international partners of them. The Foreign Policy Report of 2019 mentions climate change 19 times, in contrast to previous reports, which refer to climate change three times on average annually. The Foreign Policy Report of 2019 puts climate change in various thematic contexts: security, environment, economy and social affairs. Yet, the main focus on climate change relates to Latvia's policy in the EU and argues that climate change is "a priority of the Member States and the new European Commission" and given the decision of the US to withdraw from the Paris Agreement "it is in the interest 
of the EU to implement a single and ambitious climate policy" (Ministry of Foreign Affairs, 2019). Latvia thus aligns with the EU goal of carbon neutrality by 2050 and asks for the allocation of an adequate EU budget. Latvia defines itself as an actor in tackling climate change and thus seeks to rebrand itself at the identity narrative level as a pragmatic and responsible partner within the EU, one which is an active promoter of EU climate ambitions.

Third, climate change has found its place in several basic policy planning documents. For example, the Latvian National Development Plan for 2021-2027, a mid-term planning document for public investment, uses the keyword 'climate' and its derivatives 33 times. In contrast, the previous National Development Plan for 2014-2020 does not have such a keyword at all. The most recent National Development Plan (Cross-Sectoral Coordination Centre of Latvia, 2020) states: "Latvia is still moderate in terms of climate, but not in terms of attitude towards global climate change". An economy that works for people at the same time using opportunities, offered by climate change, emerges as a narrative at the issue level pointing to Latvia's future development driven by green growth. For such growth, the Plan proposes action that is sustainable but at the same time benefits Latvia's economy, which indicates pragmatism.

Finally, concrete commitments have been included in sectoral policy documents. On 17 July 2019 the Latvian Cabinet of Ministers approved the Latvian National Plan for Adaptation to Climate Change until 2030 and on 28 January 2020 - the Latvian Strategy for Carbon Neutral Development until 2050. The latter advocates Latvia's carbon neutrality by 2050, strategically achieved by reducing greenhouse gas (GHG) emissions across all sectors of the economy and by absorbing larger amounts of $\mathrm{CO}_{2}$. In 2020, Latvia submitted to the European Commission an updated National Energy and Climate Plan 2021-2030 with more ambitious plans than the 2018 draft version of the document which had been deemed as not very ambitious by the European Commission (Ministry of Economics, 2018). Latvia has increased its national ambitions for 2030, aiming to reduce the GHG emissions by $65 \%$ and to ensure a $50 \%$ share of energy produced from renewable resources in its final energy consumption by 2030 (Ministry of Economics, 2020). At the issue narrative level, adoption of sectoral planning documents with ambitious goals demonstrates Latvia's commitment to action.

\section{Rebranding Latvia as a North European country}

A narrative of belonging and "returning to Europe" (Ūdris, 2004) has been a powerful narrative in post-Soviet countries -including Latvia - to justify joining the EU, and it has mobilised governments and societies to implement painful reforms. Yet, the label New Member States (see Hagemann, 2019; Grdesic, 2019; Bego, 2015), is still a common frame through which countries that joined the EU in 2004 or later are viewed. Arguably, more than fifteen years after joining the EU, the narrative does no longer suit political elites and societies of post-2004 accession countries, as it does not describe the reality of being part of EU decision-making with access to information and power leverages. They, therefore, seek to redefine their image in the EU.

The rebranding of Latvia in the EU as an equal partner comes together with Latvia's efforts to minimise the perception of Latvia as an East European country. Aiva Rozenberga (Latvijas Sabiedriskie Mediji, 2019), former director of the Latvian Institute (responsible for Latvia's image and branding) and current advisor to the President of Latvia, maintains that Latvians would like to be associated with dynamics and success, and "Northern 
Europe is something of a success associated with good image in the world". She continues to argue that Latvians should stop repeating that "we are from Eastern Europe" (Latvijas Sabiedriskie Mediji, 2019). Indeed, for many "East European" is not only a geographic concept. It entails associations with communist or post-communist country in transition, lagging behind in reforms. During the Cold War, the Iron Curtain symbolized the EastWest divide. Nowadays, many of the countries of the so-called Eastern Bloc have joined the EU, yet their perception as post-communist has remained. ${ }^{2}$ Given this, Latvia's efforts to rebrand itself as a North European country have to be understood as part of more general attempts by politicians and society to rid Latvia of its communist past and legacies.

Karinšs embodies the efforts of the Latvian government to rebrand Latvia as a North European country at the identity narrative level. The issue narrative of Latvia as an active promoter of a carbon-neutral climate policy is part of constructing Latvia's identity as a pragmatic EU partner and relies on the image of the successful Nordic EU Member States, which are seen as taking care of their citizens and environment. Karinš thus attempts to align the narratives at system, identity and issue levels to construct a consistent national narrative of Latvia as a pragmatic actor in a world full of uncertainties.

The empirical analysis of this study reveals that out of eight speeches by Kariņš, four speeches include direct references to Latvia as a North European country. Importantly, with the North European identity narrative, Karinšs seeks to address both European and domestic audiences. Addressing the European Parliament, Kariņš (2019b) emphasises that "Latvia has a long history as part of the Northern European cultural area", and "we have gone through the Renaissance, Reformation, and Enlightenment". From the perspective of narrative structure, embeddedness in the Northern European cultural space is Latvia's past, but it is also Latvia's future. In this regard, being 'East European' is only an unfortunate transitional stage, caused by Soviet occupation as a result of the Second World War. Kariňš (2019b) compares: "In 1984, Latvia seemed like a different world from the West [...] Everything was monotone and in Russian [...] It was a visibly occupied country". Yet "in 1991, things started to change rapidly". By joining the EU and NATO in 2004 Latvia "returned" to Europe (Ūdris, 2004), which it was forcefully cut off from in 1941. The thematic scene of such a narrative is normative and suggests that Latvia has historical and cultural roots in the "enlightened" Europe (Wolff, 1994).

At the domestic level, the economy sets the thematic scene of the narrative. Kariņs acknowledges poverty and inequality which persists in Latvian society ${ }^{3}$ and remarks on constantly inadequate funding for health and education. For him, the resolution is the Nordic model of development. He states:

Our way forward must be to achieve greater levels of prosperity in the country by reducing inequalities and by promoting more trust in each other and public administration in general. I have simply named this development as a "path to the Nordic welfare level' (Kariņš, 2019a).

To achieve the level of welfare of the Nordic countries, Kariņš appeals to certain characteristics of the Self, i.e. Latvia as an actor: the patience and hard-working capabilities of the Latvian people. Informing the Parliament on his government's progress Kariňš (2019d) explains that welfare "is not an objective that is achievable in a single day, week, month or year, but it is an objective that we will achieve step by step". In the

${ }^{2}$ See, for example, news in media: Hala, M. (2018), Politico (2016), Silva, I., Parrock, J. (2020).

${ }^{3}$ According to Eurostat (2020a) one fourth of the Latvian population is living at risk of poverty. 
parliamentary debates on Latvia's budget for 2020 Kariņš (2019c) maintains: "We aspire, we work and we will achieve the well-being of these Nordic countries".

Though Kariņš narrative of Latvia's belonging to Northern Europe does not touch upon climate change directly, it provides a prospective ideological background for an alignment with the narrative of an active promoter of carbon-neutrality. Northern European countries enjoy an image in Latvia as strong welfare states caring about the environment. According to the narrative, if Latvia was and would like again to be a North European country (and prosper), it cannot ignore climate change issues. Tackling climate change has economic benefits as well, which has been emphasised at the issue narrative level: climate change provides an opportunity to develop technologies, create jobs and prosper from new economic possibilities. Addressing Parliament during the 2020 foreign policy debates, Kariňš (2020) asserts that climate change is an "enormous" economic opportunity, as the EU "with directives and regulations guarantees - guarantees! - the market of 500 million people for technologies that will be able to reduce greenhouse gas emissions, ensure energy efficiency and renewable energy production". Therefore, ambitious climate change policy at the issue narrative level is instrumental to Latvia's "path to the Nordic welfare level" (Kariņš, 2019a).

As to the structure of the narrative, Karinšs constructs an identity narrative of Latvia as a pragmatic and reliable partner in the EU, thus responding to institutional constraints posed by the EGD. Latvia is the main actor in the narrative, with its inhabitants described as "pragmatic, patient, rational and law-abiding" (Kariňš, 2019b). To be considered an equal partner, Latvia engages in action through policies that actively seek to tackle climate change - a policy area, which it long has been passive in. By aligning narrative and action, the Latvian government seeks to further strengthen its image as a North European country. Importantly, Latvia collaborates with other actors and joins the EU member states that advocate a more ambitious EU strategy on carbon-neutrality. In doing so, Latvia's narrative and action join to pursue not only a strategic interest or support a common good but also to strengthen Latvia's image as a pragmatic and reliable partner in the EU. Whereas normative assumptions underlie Latvia's North European narrative, directed at international audiences, economy dominates the scene of the narrative at a domestic level. Kariņš action is aimed towards reducing poverty and inequality, which is the main conflict persistent in Latvian society. The level of welfare of North European countries is the proposed resolution to the conflict. Action in the realm of climate change provides opportunities for Latvia's economy to prosper.

\section{Concluding remarks}

This study focused on Latvia's efforts to deal with changing institutional and environmental contexts, as evidenced by climate change and the EU's ambitions in becoming a world-leader in climate change policies. By drawing on a strategic narrative framework, the study demonstrated how the Latvian Prime Minister seeks to rebrand Latvia as a North European country on an identity narrative level, reorienting Latvia from a passive observer to an active promoter in climate policy. Latvia's political narrative can be considered a pragmatic narrative: a narrative that considers the inevitable reality of climate change and emphasises the opportunities in tackling it. The narrative touches upon Latvia's past as belonging to the North European cultural space and draws its future as a North European country seeking to reach a level of welfare comparable to that of the Nordic countries. By actively pursuing climate change policies, the Latvian Prime Minister promotes an image of Latvia as a pragmatic and equal partner in the EU, and, at the same 
time, aims to benefit from the opportunity climate change policies provide for the Latvian economy.

Such a narrative has several implications for Latvia. In a country with high income inequality levels and one fourth of the population living at risk of poverty (Eurostat, 2020a), a narrative that puts at its centre the values and the example of wealthy North European countries, is decisively appealing to domestic audiences. Externally, the narrative positions Latvia, as a pragmatic and reliable partner in the EU and thus adds to Latvia's bargaining power in EU negotiations. At the same time, the strategic narrative framework acknowledges that actors can be trapped in their narratives. In Latvia's case, it implies that the narrative of being an active promoter in tackling climate change requires Latvia to implement relevant measures at home. The first test for the Kariņš government to align narrative and action to ensure credibility, will be the allocation of adequate resources dedicated to carbon-neutrality, especially in the light of the Covid-19 pandemic and the necessity to overcome the crisis. The viability of the narrative also depends on the resonance of the narrative both externally (among Latvia's EU partners, in EU institutions, in Latvia's neighbourhood) and internally (projection of the narrative in media ecology, perceptions of different societal groups). Rhetoric around government hypocrisy around implementing climate policies may find receptive audiences, given the low trust of the Latvian population in state institutions and political parties (see European Commission, 2018) and a long-term perception of corruption at the highest political level.

With the focus on the member state level of the EU's strategic narrative on climate change, this study adds a domestic dimension to EU perception studies. Overall, this study illuminates that narratives matter in explaining how EU member states deal with change and legitimise their stance given certain institutional limitations. In Latvia's case institutional constraints have enabled a pragmatic narrative, fostering Europeanisation in the realm of climate policy. The concept of strategic narrative provides a useful framework for grasping discursive constructions actors use to justify their actions in circumstances of institutional constraints. Merging the approaches of rational institutionalism and strategic narratives thus allows explaining not only the fact that actors adopt certain EU norms following cost-benefit analysis but also the communicative processes around it even within certain institutional constraints.

\section{References}

Bego, I. (2015). Gender Equality Policy in the European Union. A Fast Track to Parity for the New Member States. Palgrave Macmillan.

Baltic News Network (2012, January 27). EPI: Latvia is the second greenest country in the world. https://bnn-news.com/epi-latvia-greenest-country-world-47902

Bruner, J. (1991). The Narrative Construction of Reality. Critical Inquiry 18 (1), 1-21.

Cabinet of Ministers (2019, May 10). Kariņš: Eiropas Savienības klimata politika ir iespēja Latvijas tautsaimniecībai [Press release]. https://www.mk.gov.lv/lv/aktualitates/karins-eiropas-savienibas-klimatapolitika-ir-iespeja-latvijas-tautsaimniecibai

Cernoch, F., Lehotský, L., Ocelík, P., Osicka, J.,\& Vencourová, V. (2019). Anti-fossil frames: Examining narratives of the opposition to brown coal mining in the Czech 
Republic. Energy Research \& Social Science 54 (August), 140-149. https://doi.org/10.1016/j.erss.2019.04.011

Chaban, N. \& Holland, M. (eds) (2014). Communicating Europe in times of crisis : external perceptions of the European Union. UK: Palgrave Macmillan.

Chaban, N., Miskimmon, A. \&O'Loughlin, B. (2017). The EU's Peace and Security Narrative: Views from EU Strategic Partners in Asia. Journal of Common Market Studies 55(6), 1273-1289. https://doi.org/10.1111/jcms.12569

Cross-Sectoral Coordination Centre of Latvia. (2014). National Development Plan of Latvia 2014-2020.https://www.pkc.gov.lv/sites/default/files/inlinefiles/NDP2020\%20English\%20Final 1.pdf

Cross-Sectoral Coordination Centre of Latvia. (2020). Latvijas Nacionālas Attīstības Plāns 2021.-2027.gadam.https://www.pkc.gov.lv/sites/default/files/inlinefiles/NAP2027galaredakcija.pdf

Emerson, J. W., Hsu, A., Levy, M. A., de Sherbinin, A., Mara, V., Esty, D. C. \& Jaiteh, M. (2012). 2012 Environmental Performance Index and Pilot Trend Environmental Performance Index. http://ciesin.columbia.edu/documents/2012-epi-fullreport.pdf

European Commission. (2019, September). Special Eurobarometer 490. Climate Change. https://ec.europa.eu/commfrontoffice/publicopinion

European Commission (2018, Autumn). Standarta Eirobarometrs 90. Nacionālais ziņojums: Latvija. https://ec.europa.eu/commfrontoffice/publicopinion

Eurostat (2020a). Europe 2020 indicators - poverty and social exclusion. https://ec.europa.eu/eurostat/statistics-explained/index.php?title=Main Page

Eurostat (2020b). Renewable energy statistics. https://ec.europa.eu/eurostat/statisticsexplained/index.php?title=Main Page

Graziano, P.R. (2012). Europeanization and Domestic Policy Change: The Case of Italy. London/New York: Routledge.

Grdesic, M. (2019). Who Are the Neoliberals in Central and Eastern Europe? Assessing Public Support for Neoliberalism in 11 New EU Member States. Europe-Asia Studies, 71(10), 1645-1663. https://doi.org/10.1080/09668136.2019.1656710

Hagemann, C. (2019). EU Funds in the New Member States. Party Politicization, Administrative Capacities, and Absorption Problems after Accession. Palgrave Macmillan.

Hala, M. (2018, April 13). Europe’s new 'Eastern bloc”. Politico. https://www.politico.eu/article/europes-new-eastern-bloc-china-economymodel-belt-road-initiative/

Hall, P. A. \& Taylor, R. C. R. (1996). Political Science and the Three New Institutionalisms. Political Studies, 44(5), 936-957. https://doi.org/10.1111/j.1467-9248.1996.tbo0343.x 
Kariņš, K. (2019(a), January 1). Ministru prezidenta Krišjāṇa Kariņa apsveikums Jaunajā gadā [Speech]. https://www.mk.gov.lv/content/ministru-prezidentakrisjana-karina-runas

Kariņš, K. (2019(b), April 17). The Future of Europe [Speech] https://www.mk.gov.lv/content/ministru-prezidenta-krisjana-karina-runas

Kariņš, K. (2019(c), October 30). Ministru prezidenta Krišjāṇa Kariņa runa Saeimas debatēs par 2020. gada budžeta likumprojekta izskatǐ̌̌anu 1. lasījumā [Speech]. https://www.mk.gov.lv/content/ministru-prezidenta-krisjana-karina-runas

Kariņš, K. (2019(d), November 14). Ministru prezidenta Krišjāṇa Kariṇa uzruna Saeimā par Ministru kabineta paveikto un iecerēto darbību [Speech].

https://www.mk.gov.lv/content/ministru-prezidenta-krisjana-karina-runas

Kariņš, K. (2020, January 23). Ministru prezidenta Krišjāņa Kariņa uzruna Saeimas sēdē 2020. gada 23. janvārī, ikgadējās ārlietu debatēs [Speech]. https://www.mk.gov.lv/content/ministru-prezidenta-krisjana-karina-runas

Kundzewicz, Z.W., Painter J. \& Kundzewicz W.J. (2019). Climate Change in the Media: Poland's Exceptionalism. Environmental Communication, 13(3), 366-380. https://doi.org/10.1080/17524032.2017.1394890

Lehotský, L., Cernoch, F., Osicka, J.,\& Ocelík, P. (2019). 'When climate change is missing: Media discourse on coal mining in the Czech Republic. Energy Policy, 129 (June), 774-786. https://doi.org/10.1016/j.enpol.2019.02.065

Investment and Development Agency of Latvia (2015) Environment and Renewable Energy. Industry In Latvia.

http://www.liaa.gov.lv/files/liaa/attachments/liaa environment catalogue m 4.pdf

Latvijas Sabiedriskie Mediji (.2019, May 3). Latvijas Institūta bijusī vadītāja: Latvija ir Ziemel̦eiropas daļa.. https://www.lsm.lv/raksts/zinas/latvija/latvijas-institutabijusi-vaditaja-latvija-ir-ziemeleiropas-dala.a317844/

Ministry of Economics (2018). Latvia's National Energy and Climate Plan 2021-2030 (Draft submitted to the European Commission). https://ec.europa.eu/energy/sites/ener/files/documents/latvia draftnecp en.pd $\underline{\mathrm{f}}$

Ministry of Economics (2020). Latvia's National Energy and Climate Plan 2021-2030. https://ec.europa.eu/energy/sites/ener/files/documents/lv final necp main e $\underline{\text { n.pdf }}$

Ministry of Foreign Affairs (2019). Ārlietu ministra ikgadējais ziņojums par paveikto un iecerēto darbību valsts ārpolitikā un Eiropas Savienības jautājumos 2019. gadā. https://www.mfa.gov.lv/aktualitates/zinas/65188-arlietu-ministra-ikgadejaiszinojums-par-paveikto-un-iecereto-darbibu-valsts-arpolitika-un-eiropassavienibas-jautajumos-2019-gada

Miskimmon, A., O'Loughlin, B. \& Roselle, L. (2013). Strategic narratives: communication power and the new world order. New York, London: Routledge. 
Osička, J., Kemmerzell, J., Zoll, M., Lehotský, L., Černoch, F. \& Knodt, M. (2020). What's next for the European coal heartland? Exploring the future of coal as presented in German, Polish and Czech press. Energy Research \& Social Science, 61 (March). https://doi.org/10.1016/j.erss.2019.101316

Politico. (2016, January 13). Is Poland a failing democracy? https://www.politico.eu/article/poland-democracy-failing-pis-law-and-justicemedia-rule-of-law/

Ruse, I. (2013). (Why) Do Neighbours Cooperate? Institutionalised Coalitions and Bargaining Power in EU Council Negotiations. Verlag Barbara Budrich.

Roselle, L., Miskimmon, A. \& O’Loughlin, B. (2014). Strategic narrative: A new means to understand soft power. Media, War \& Conflict, 7(1), 70-84. https://doi.org/10.1177/1750635213516696

Saeima. (2019(a), September 26). Par Nacionālās drošības koncepcijas apstiprināšanu. Latvijas Vēstnesis. https://likumi.lv/doc.php?id=309647

Saeima. (2019(b), September 26 ). Latvijas Republikas 13. Saeimas rudens sesijas ceturtā sēde 2019. gada 26. septembrī [Transcript]. https://www.saeima.lv/lv/transcripts/view/2010

Schimmelfenning, F. \& Sedelmeier, U. (2005). The Europeanization of Central and Eastern Europe. Cornell University Press.

Silva, I. \& Parrock, J. (2020, January 27). The Brief: corruption still a major issue in European Union. Euronews. https://www.euronews.com/2020/01/27/the-briefcorruption-still-a-major-issue-in-european-union

Ūdris, J. (2004, May 27). Latvijas de facto atgriešanās Eiropā: Rihards Pīks, Latvijas Republikas ārlietu ministrs intervijā "Latvijas Vēstnesim”.Latvijas Vēstnesis. https://www.vestnesis.lv/ta/id/89156

Wendling, Z. A., Emerson, J. W., Esty, D. C., Levy, M. A., de Sherbinin, A., \& al. (2018). 2018 Environmental Performance Index. New Haven, CT.https://epi.yale.edu/

Wolff, L. (1994). Inventing Eastern Europe: The Map of Civilization on the Mind of the Enlightenment. Stanford: Stanford University Press. 